\title{
Overcoming the Forest Fire in West Kalimantan: A Political Ecology Approach
}

\author{
Elyta Elyta ${ }^{1}$, Ishaq Rahman ${ }^{2}$ \\ (elyta.elyta79@gmail.com¹, ishaq@unhas.ac.id²) \\ ${ }^{1}$ Faculty of Social and Political Sciences, Tanjungpura University, Pontianak, Indonesia \\ ${ }^{2}$ Faculty of Social and Political Sciences, Hasanuddin University, Makassar Indonesia
}

\begin{abstract}
Forest fires have become one of the calamity in Indonesia and neighboring countries, a detrimental effect of uncontrolled licensing for investment in the plantation sector. This study aims to explain the existence of a political ecology approach in overcoming forest fires in Rasau Jaya District, Kubu Raya Regency. By applying qualitative descriptive methods, researchers conducted interviews with several resources person from related institutions and fire care groups. Two actors, namely government and non-government actors, played a critical role through the political ecology approach. Both actors have created a responsive political will in dealing with forest fires. At the same time, both actors raise public awareness by promoting public responses to fire.
\end{abstract}

Keywords: political ecology, social movement, forest fire

\section{Introduction}

West Kalimantan Province consists of 14 local governments, namely 12 municipalities and two cities. Every year, especially during the dry season in April to September, burning of land and forests occurs. Smog covers most of West Kalimantan area, spread to reach neighboring countries, including Malaysia, Singapore, and Brunei Darussalam. The most obvious impact of this smog is a decrease in air quality; reduced visibility (which greatly interferes with land, sea and air transportation); and the distraction of a community's socioeconomic activities.

Forest and land burning are one of the methods to weed out the land before engraining new plants. People choose this method because it is more practical, faster, cheaper and easier. However, due to a lack of precaution in the process of burning of land, the land fires growth to become a disaster, including in West Kalimantan region. Data from the West Kalimantan Province Plantation Office show the number of hotspots of land and forest fires. Between 2006 and 2015, there were at least 53,715 hotspots throughout the Province. The three regions that have the largest hotspots are Ketapang District (which reaches 13,541 hotspots), Sintang District (which reaches 6,575 hotspots) and Sanggau District (reaching 6,466 hotspots) during this period [1].

One reason for the high cases of land and forest fires is low public awareness of the dangers of using fire [2] and the negative impact of land fires and smog [3]. Also, the negative impact of land fire is serious. Ecologically, the haze that comes from forest fires has lower air quality, which hurts health. Acute Respiratory Tract Infections (ARI) are widespread [4]. However, people tend to ignore the negative impacts and continue to burn to open and clear plantation land. 
The government has made various efforts to minimize this annual incident, but the results have not been satisfied. Several programs, like the zero burning policy or a national campaign to control forest burning, has not provided a maximum result. For example, the government held the national alert briefing (Bahasa: apel siaga nasional) in South Sumatra in 2006. The hotspots increase up to $1000 \%$ in the same year [3]. Among several determinant factors, low awareness of the community has provided the increasing of land burning activities [5] even though the government, especially security apparatus, continues to enforce the law regarding land and forest fires [6].

Furthermore, mismanagement of forest exploitation is the urgent problem regarding forest and land damage which shows a correlation indicator of failure over forest management among actors - for example, the department of forestry, both in central and regional agencies and both local and transnational entrepreneurs. They are often careless to implement environment-based forestry development concepts and systems [7]. Based on the phenomenon, forest management policies implied in low enforcement without strict sanction for violators has become the influencing factor in increasing forest and land fires.

Conceptually, ecological politics emphasizes the approach to combine attention to the environment and political economy in forest management. As a result, the emergence of 'deforestation' is seen from the perspective of economic politics because of centralized government policies. In regard, the government centrally controls the management of natural resources. On the other hand, development planners and forestry bureaucrats are very eager to control the behavior of forest concession holders (HPH) concessions and do not pay attention to environmental impacts which ultimately leads to widespread destruction of forests. Because of mismanagement for the forest, exploitation has resulted in damage to the environment, damage to customary forest rights, land conflicts and marginalization of local communities in the management of forest resources.

Thus, this study aims to examine the factors underlying the rampant forest and land fires that have occurred in West Kalimantan. By using a political ecologicy perspective, namely by examining the efforts of various actors in implementing policies that lead to environmental conservation to overcome land and forest fires in Kalimantan West, focusing on two main categories of actors in the political approach, namely state and non-state actors.

\section{Political Ecology Approach}

Journal articles, scientific papers, and reports that use the political ecology word or phrase in the title are increasingly appearing. Interestingly, these topics come from varied disciplines. This approach was initially a response to the symptoms of massive environmental damage in the 1960s and 1970s because of modernization. Several studies on the damage to the environment associated with public policy and political space [8]-[12].

In contrast to other approaches in environmental research, the ecological approach usually applies a radical perspective [13]. The researchers of this topic were originally neo-Marxist thinkers who dominated environmental academic works in the 1970s and 1980s. The main characteristic of a radical perspective is that environmental damage is the result of greed and does not care about capitalism, which continues to exploit natural resources.

In the present perspective, political ecology is a relatively new field in human geography [14], an approach that not only criticizes non-environmentally friendly behavior by capitalism but also offers solutions that environmental stakeholders can take to overcome environmental problems. In research on human geography, the role of actors gets severe attention, which based on general assumptions in social/cultural geography [15]. 
The political ecology approach in explaining and finding solutions to forest fires in Indonesia still seems to focus on efforts to overcome or overcome fires [16]. Meanwhile, environmental issues are increasingly gaining a place in the political hemisphere in Indonesia [17]. These give space for efforts to identify the role of political actors, especially in the polarization of state and non-state actors [18], in overcoming land and forest fires comprehensively.

\section{Methods}

The researcher applied a qualitative descriptive method through in-depth interviews with five key resource persons, namely:

1. Head of the Regional Disaster Management Agency (Badan Penanggulangan Bencana Daerah or $\mathrm{BPBD})^{1}$ of West Kalimantan Province whose role is to coordinate forest and land fire control in the province,

2. Head of the West Kalimantan Province Environmental Impact Management Agency (Badan Pengendalian Dampak Lingkungan or BAPEDAL) as the organizer to prevent and control pollution and environmental damage and restoration of quality of the environment;

3. The Head of the West Kalimantan Province Forestry Division, who acts as the coordinator who prepares regional policies concerning land and forest fire prevention and control,

4. Head of the Plantation Division of West Kalimantan Province;

5. Informal figures, including NGO's that, know land and forest fire problems in the community level.

The researcher uses a "political ecology" perspective to conduct analysis, which explains the role of various actors in implementing policies that lead to environmental preservation.

\section{The Role of Actors in Overcoming Forest Fire in West Kalimantan}

\subsection{Government Actors}

Political ecology has the perception that the power gap in managing ecology creates bounce back effects for humans that destroy the environment. People who cannot control their power will act arbitrarily in enjoying natural products [19]. Management of environmental control often disregarded [20].

According to the Head of the BPBD, although there have been regulations to control forest and land fires, the reality in the field is still widespread land and forest fires caused by weak legal aspects that ensnare the perpetrators of forest burning and there has been no innovation for the community to manage the land into agricultural fields.

The Head of the Plantation Division of West Kalimantan Province said that the province has around 14,000,000 hectares, almost 13,000,000 hectares granted permits for plantations and mining. The rest (i.e., around 1 million hectares) is allocated for housing, farming and agricultural. In 2016, there were 125 villages mapped for potential areas of forest and land fires, especially in peatland areas. Strict supervision aims to prevent that area from avoiding local inhabitant using fires to clean the land.

Natural resources scarcity, as well as environmental protection, has recorded as one of a global issue in today's world. Unfortunately, countries in the world have reached no agreement to solve them yet [21]. To answer this lack in government level, strengthening

${ }^{1}$ The term BPPD will be using repeatedly throughout this article. 
political groups is one of the necessary ways to increase public awareness [21]. This study shows that the implementation of strengthening government actors at the provincial level (Plantation Division, Forest Service Division, and Mining Division of West Kalimantan Provincial Government) by collaboration with the Ministry of Forestry through a forest firefighting unit called Manggala Agni. The collaboration focused on supervising the land that planned to transform into oil palm plantation. As the coordinating agency, BPBD has appealed every district and city to take part in the collaboration.

Manggala Agni promotes public awareness at the community level so as not to burn when clearing land, especially in fire-prone environmental conditions. Farmers generally do not realize the meaning of being environmentally friendly, so there are still people who burn the land. That is why Manggala Agni continuously share information regarding the calamity threat that could come from careless handling of clearing land-using fire.

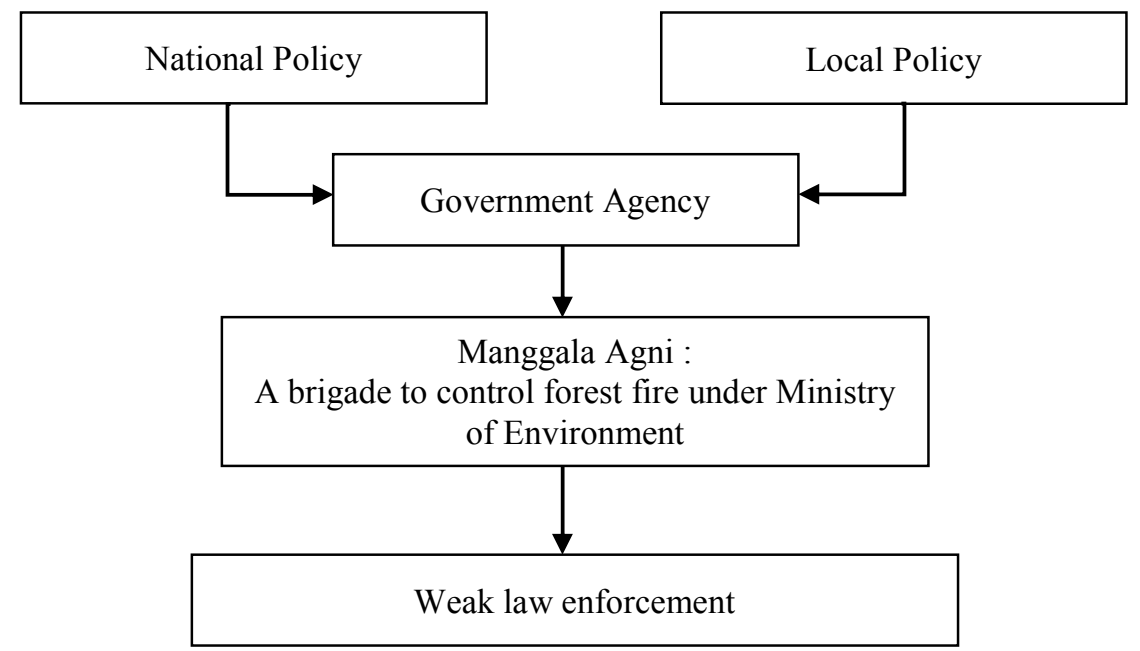

Fig. 1. Flow of Government Actors Movement

Source: Provided by authors, 2019

Another issue related to the political ecology approach in handling forest and land fires is social inequalities. The interaction gap occurs between the people who have power (mostly political power) with people in control [19]. The central government, as the ruler class, warns the companies that the government can revoke their permit if they burn the land and caused forest and land fires. However, in reality, such warning ignored by particular companies, especially the big ones. Sometimes, the company pays a local citizen to burn land. When unwanted land fires occur, the company can leave freely.

Finally, in the context of political ecology, each level of local government in West Kalimantan has a certain authority in terms of overcoming the forest and land fires. Head of the BPBD explained that if the incident of forest and land fires occurs, the district government should handle it in a maximum of three days. If they fail to extinguish the fire, the provincial government will take the command, and mobilize the appropriate resources. If the escalation of fires is getting bigger and provincial government fail to lever it, than national authority will 
take control of the command line, particularly through the National Disaster Management Agency (Badan Nasional Penanggulangan Bencana or BNPB).

The figure 1 , shows that the government through the central authority provides coordination to the local government as the continuation of the national policy to be implemented by government agencies at the local level. Government agencies carry out tasks to handle forest fires by forming a task force, one of which is the central government forming the Manggala Agni Brigade. Also, the brigade not only helps in dealing with forest and land fires but also other fires occurs in and around the forest.

Based on the Law Number 41 of 1999 concerning Forestry in article 50 paragraph 3 point $\mathrm{d}$ states, "everyone is prohibited from burning the forest." Sanctions imposed with a maximum 15 years of imprisonment and a maximum fine of five billion rupiahs. Furthermore, the regional government enacted the Regulation Number 06 of 1998 concerning Prevention and Control of Forest and Land Fires, which includes a series of strict sanctions for violators, and parties involved in forest and land fires. As a follow-up to this regional, the West Kalimantan provincial government issued Governor Regulation Number 103 of 2009 concerning the Standard Operational and Procedures for Mobilization of Resources to Control of Forest and Land Fires in West Kalimantan Province. By using this regulation, there is formal legal umbrella mobilize the resources that local governments have in controlling forest and land fires.

\subsection{Non-Government Actors participation in overcoming the forest and fires in West Kalimantan}

The community plays an active role to back up government activities in tackling forest fires. The community has progressive initiatives, by form a group consisting of people who care about the issues. This group is often called a non-government actor because the group is not from the government but only ordinary citizens who have a high level of concern to environmental issues, particularly forest fire. At the district level, a working group will be formed and deployed to villages through the village escort team (Tim Pendamping Desa, TPD). Subsequently, the local government re-formed a group specifically dealing with fires called fire care groups. This fire care group will have assistance activities that aim to improve the economy, to control fire, and to make the village independent and environmentally friendly.

According to political ecology perspectives, public awareness considered as a key factor from the society side to protect the environment [19]. Although society has independencies in deciding their role, the case of West Kalimantan province shows that in many occasion government needs to more actively. The head of the West Kalimantan BPBD stated that socialization and awareness raising activities were carried out by visiting residents door to door, establishing associations in the village head's office (or at home of an influential figure in the village), followed by the distribution of campaign materials such as flyers and brochures. The BPBD also called on communities to implement a Non-Burning Land Opening (Pembukaan Lahan Tanpa Bakar or PLTB) system to prevent the forest and land fire. The government also introduced a planting method using tri coderma and sea mud. The method needs a higher cost, but it can increase from four to five times more effective. 


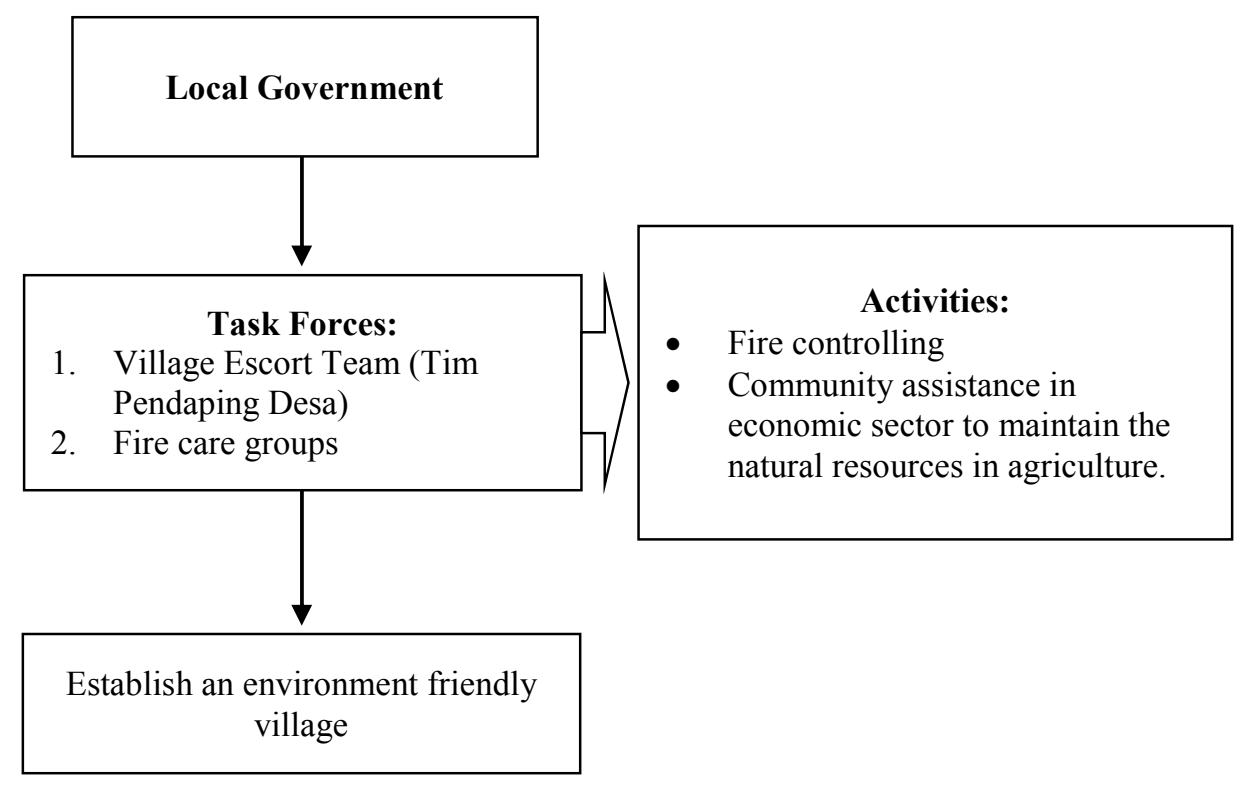

Fig. 2. Flow of Non-Government Actors Movement

Sources: Provided by authors, 2019

The Plantation Division, the Forest Service Division and the Mining Division of West Kalimantan Provincial Government have formed three fire care groups, located in Rasau Jaya, Kubu and Kuala Mandor B. In addition, the Plantation Division, Forestry Service Division and Mining Division also support three other fire care groups (formed by the provincial government) in Sungai Ambawang District, Kubu Raya Regency. The three agencies also collaborated and coordinated with related agencies at the provincial to the sub district level to build similar visioning on how to combat forest and land fires comprehensively.

The disaster management system consists of three stages, namely pre-disaster management (for preventive measures), emergencies action (actions in the event of a disaster), and rehabilitation program (for post-disaster recovery stages). The role of non-government actors can be a driver of law enforcement, particularly local government regulations. Also, there is training for prevention before a disaster occurs and implementing approaches to the community, apparatus, and non-governmental organizations.

Based on findings in the field, people who do not understand the law are more obedient to the law. The government has warned that law enforcement officer can arrest land-burners, and police can detain them. This warning quite effective to create a deterrent effect, so people are encouraged to stop burning. On the other hand, for people who already understand the law, they tend to argue that the fires they burn are very tiny; compare to what big companies (such as oil palm companies or housing contractors) burns. The problems are, law agency tends to ignore most of the cases involving big companies; therefore, it becomes a bad precedent for the community.

The Head of BPBD stated that every year a plan document was renewed and evaluated, due to changing pattern in the prediction of forest and land fires. For example, the area of forest and land fires predicted to be 200,000 hectares, but it is possible to get bigger to around 
300,000 hectares. The number of firefighters is around 250-300 people. BPBD has attempted to deal with the impacts of forest fires through a plan for consistency in handling these disasters, which includes all shareholders, such as government and community institutions, police officers, Indonesian national soldiers at the district/city level. This consistency plan clearly described the roles, tasks, and resources that each agency has to mobilize to address forest and land fires incident. The document uses as a guide to carrying out the duties of staffs who will be parts of mobilization.

Community, by the support of government, involved in prevention and mitigation efforts jointly and independently. For the implementation of the formation of the Fire Care Group (Bahasa: Kelompok Peduli Api or KPA) which is currently carried out by the community, KPA is merely a formality and tends only to fulfill instructions. Therefore, for the future, it is important to record that KPA can carry out the prevention and handling of land fires, which are its main tasks and functions.

Another issue related to community involvement is the economic value of the land. People always assume that unused (or abandoned) land has no economic value. Therefore, they tend to ignore this kind of land. The community is only focusing on fire prevention on land that has economic potential. This kind of idea probably true, but not at all, especially when we deal with political ecology. The impact of forest and land fires are not only related to the economic value of land but also widespread to other engagement. For example, when the unused or abandoned land gets burns, the smoke comes from it will be the same with smoke that comes from economically valued land.

Its utilization for residential areas and agricultural activities for seasonal food crops still requires further consideration. Technically, peatland can be more useful as a conservation area. Furthermore, the cultivation of conservation values such as smallholder rubber plantations that results can be relevant to the aspirations and conditions of the community, optimization of programs and reducing the risk of failure.

\section{Conclusion}

The government actors movement in dealing with the forest fires is through policies, reaffirmation, and supervision to control the occurrence of forest fires, especially for the Province of West Kalimantan. The government's reference is the national law and provincial regulation. Through this policy, several agencies collaborated in the handling of forest fires, including the involvement of the unit created by national ministry such as the Manggala Agni. The policy is what the ecological, political approach that can have an impact on the environment.

The non-government actor movement can be a key position, both in positive terms (namely reducing the level of forest fires) and in negative matters (such as being the perpetrators of forest fires). Furthermore, these non-government actors have a positive effect by socializing government policies related to forest protection. Also, movements are carried out by raising awareness of the importance of protecting forests by changing the behavior of land clearing, from burning to other ways. These non-government actors create a real change and directly interact with the issue in the field and empower communities through mentoring.

\section{Recommendation}

Efforts to improve the role of the community for prevention and control of land fires require commitment and coordination of the community and government, especially in the implementation stages. Solving the problem of land and forest fires must be from the source, 
namely increasing knowledge and awareness about the importance of protecting the environment, and about the negative impact of land fires. For this reason, the ability of the community to manage land properly is necessary.

\section{References}

[1] Dinas Perkebunan Kalimantan Barat, "Pemantapan Koordinasi Pemantauan Dini Potensi Kebakaran Kebun Serta Persiapan Peralatan Pengendalian Kebakaran Kebun di Kalimantan Barat," Pontianak, 2016.

[2] R. Fachmi, "Permasalahan dan Dampak Kebakaran Hutan," J. Lingk. Widyaiswara, vol. 1, no. 4, pp. 47-59, 2014.

[3] A. Acep, "Pengendalian Kebakaran Hutan Berbasis Masyarakat Sebagai Suatu Upaya Mengatasi Resiko Dalam REDD," Tekno Hutan Tanam., vol. 1, no. 1, pp. 11-22, 2008.

[4] Merdeka.Com, "Kebakaran Lahan dan Hutan di Kalbar, 2.000 orang Menderita ISPA," Merdeka.Com, 2018. .

[5] A. Suwari, "Penegakan Hukum Lingkungan dan Pengaruhnya Terhadap Pertumbuhan Ekonomi di Indonesia (Studi Kebakaran Hutan Tahun 2015),” J. Unifikasi, vol. 3, no. 1, pp. 1-35, 2016.

[6] Tribunnews.Com, "Pola Tetapkan 27 Tersangka dalam Kasus Kebakaran Hutan di Kalimantan Barat," TribunKaltim.Com, 2018.

[7] G. Peterson, "Political Ecology and Ecological Resilience: An Integration of Humas and Ecological Dynamics," Ecol. Econ., vol. 35, no. 3, pp. 323-336, 2000.

[8] N. L. Peluso, "The Political Ecology of Extraction and Extractive Reserves in East Kalimantan, Indonesia,” Dev. Change, vol. 23, no. 4, pp. 49-74, 1992.

[9] P. Dauvergne, "The Politic of Deforestation in Indonesia," Pac. Aff., vol. 66, no. 4, pp. 497-518.

[10] P. Blaikie, "Changing Environtment of Changing Views? A Political Ecology for Developing Countries," Geography, vol. 80, no. 3, pp. 203-214, 1995.

[11] S. Batterbury, T. Forsyth, and K. Thomson, "Environmental transformations in developing countries : hybrid research and democratic policy," Geogr. J., vol. 163, no. 2, pp. 126-132, 1997.

[12] R. L. Bryant, "Power, Knowledge and Political Ecology in the Third World: A Review," Prog. Phys. Geogr., vol. 22, no. 1, pp. 79-94, 1998.

[13] R. L. Bryant and S. Bailey, Third World Political Ecology. London and New York: Routledge, 2005.

[14] R. P. Neumann, Making Political Ecology. New York: Routledge, 2014.

[15] I. Hay, Qualitative Research Methods in Human Geography. Oxford: Oxford University Press, 2000.

[16] A. S. Suryani, "Penanganan Asap Kabut Akibat Kebakaran Hutan di Wilayah Perbatasan Indonesia," Aspirasi, vol. 3, no. 1, pp. 59-75, 2012.

[17] C. Lay, "Nilai Strategis Isu Lingkungan Dalam Politik Indonesia," J. Ilmu Sos. dan Ilmu Polit., vol. 11, no. 2, pp. 151-172, 2007.

[18] D. K. Angreta and F. Firdaus, "Local Community Tactics to Decline the Mining; Evidence from West Sumatra, Indonesia," in WESTECH 2018, 2019.

[19] Z. Arifin, "Politik Ekologi: Ramah Lingkungan Sebagai Pembenaran," J. Polit. Muda, vol. 1, no. 1, pp. 156-166, 2012.

[20] J. M. Whitehead and J. M. Rand, The Nature of the State: Excavating the Political Ecologies of the Modern State, Oxford Geographical and Environmental Studies. Oxford: Oxford University Press, 2007. 
[21] V. Rizal, "Pergerakan LSM Nol Sampah dalam Mengawal Politik Hijau Kota Surabaya Berlangganan di Kabupaten Sidoarjo: Studi Kasus Pendampingan Petani Lokal Pohon Mangrove di Bosem Wonorejo Surabaya," J. Polit. Muda, vol. 1, no. 1, pp. 156-166, 2012. 